\title{
日本の津波警報
}

勝 又 護*

\section{The Tsunami Warning Syotems in Japan}

Mamoru Katsumata

\section{I.はじめに}

最近百年足らずの間に，我が国では，人命の損失千人以上に及ぶ重大な地震桨害が10回も発生している が，5ち 2 回 (明治三陸, 死者 2 万 2 千人。昭和三陸, 死者 3 千人) は津波によるものである。また, 関東, 東南海, 南海道地震でも津波により大きな災害を受けている。このような大災害は幸いに最近40年間発生 していない。しかし，この間にも百人以上の犠牲者を出した地震災害が 2 回（チリ津波，日本海中部地震） あり，両者共津波が災害の主役となっている。

津波による災害を軽減するためには，防潮施設の建設なじ恒久的対策を構じると同時に，警報，避難な どの体制を整えておくことも重要である。ここでは，日本の津波警報体制の現状および関連する問題につ いて述べる。

\section{II. 津波警報組織の発展}

（1）昭和初期に育った人々は小学国語読本の「稲むらの火」によって，島国の宿命的災害ともいえる津 波のことを学んだ。これは, 安政南海道地震のさい, 事態の的確な判断とその迅速な伝達, 機敏な退避誘 導によって，津波から村人を救った物語である。この教えは, 地震観測網が整備され, 通信手段が発達し た今日でも変わることはない。

日本の地震学の草分として活躍した J. MILNE は， 1877 年のチリ地震（1960年の地震に次ぐ大地震， 津波は日本で $2 \sim 3 \mathrm{~m})$ の報告の中で, 早くも津波警報の可能性に言及している。

（2）我が国（扝そらく世界）最初の津波警報組織は，三陸沿岸を対象に，1941年に発足した。三陸沿岸 は，明治昭和と 50 年足らずの間に二度の大津波に見舞れたが，これらの津波は地震を感じてから30分程し て沿岸を襲っている。三陸沿岸の気象官署は，この時間差を利用して津波警報を行うことに計画一（イ） 地震後直ちに地震観測結果から震源を推定する，（口）沿岸に到達する津波の程度を地震の大きさと震央距 離から予測する，（八）津波の程度に応じてあらかじめ 3 段階の簡潔な警報文を準備しておくなど，ほぼ現 行のものの原形がこのとき出来上った。

その後，これを全国的組織に発展させようとする動きがあったが，戦争から敗戦への混乱の中に埋もれ てしまった。

（3）1946年アリューシャン列島の地震によって発生した津波は，6時間後にハワイ諸島を襲った。震央 から $3,500 \mathrm{~km}$ もはなれ，地震を知る由も無い住民は正に踙耳に水で，死者 173 人という大惨事となった。 この事件を契機に, 米国はホノルルに津波警報センターを設置した。津波からハワイ諸島を護るためには, 太平洋全域に監視網を張る必要がある。その一環として, 当時占領下にあった我が国にも協力が求められ， 地震資料や津波情報を速報し合うことになった。

* 気象研究所 The Meteorological Research Institute 
ソ連も1952年カムチャッカ地震（日本にも $3 \mathrm{~m}$ 程度の津波）のあと，極東地域の津波警報体制を整え， 日本や米国とデータ交換を行うようになった。

（4）1949年，占領軍は日本政府に対して「日本全域に対する津波警報組織を60日以内に確立し，その後 30日以内に警報機構の実施テストを完了せよ」と指示した。これをうけて，急遽津波警報組織が作られた。 多数の行政・公共機関が関点する組織が一気に実現したのは，当時の至上命令の威力によるものといわね ばならぬ。しかし，それを可能としたのは，三陸の雛形があったればこそといえる。

津波予報*はその後法規や規定を整え，1952年に正式に発足し（部分的にはいく度か改正が加えられ） 現在に至っている。

\section{III. チリ地震と遠地津波監視体制}

（1）1960年チリ沿岸沖の地震は，今世紀最大とも地震観測史上最大ともいわれる巨大なものであった。 この地震による津波は太平洋全域に波及し，チリで最大波高20 25m, 死者 1,700 人以上（地震によるもの を含む）；八ワイ諸島には約 16 時間後と $10 \sim 11 \mathrm{~m}$ の津波，死者61人；日本の沿岸には22 23時間後に $5 \sim$ $6 \mathrm{~m}$ の津波，死者 142 人；その他各地に大きな被害を与えた。

我が国の津波警報体制は，このチリ津波によって大きな衝撃を受けた。主として近海の地震による津波 （近地津波）を想定して計画されていた組織は，このような遠隔地に発生した津波（遠地津波）に効果的に 対応することができず，津波来襲後に警報を出す始末となり，世の非難をあびた。国際的にも，重要な情 報が必しも適時，適確に伝わらないなどの問題があり，各国間の組織的な協力体制を確立する必要が痛感 された。

（2）ユネスコの海洋委員会（IOC）は，1964年，太平洋沿岸諸国にとって共通の劦威である津波に備え るために，国際的な警報組織を設けることを決議，国際津波情報センター（ITIC）をホノルルに置いた。 1968年加盟国が参加して，太平洋津波警報組織国際調整グループ（ICG/ITSU）の第 1 回会議が開かれ， ホノルルの太平洋津波撆報センター（PTWC）を要として各国が協力する体制を確立した。現在 ICG/ ITSU には，太平洋沿岸および周辺の24ケ国が参加している。

日本は国内組織を強化し，PTWC と連熬し遠地津波を監視する体制を確立した。

\section{IV. 日本の津波警報組織}

（1）津波警報組織は，津波の予報を行う側，その予報を伝達する機関，抒よび予報を受けとり利用する 側の 3 者から成り立つ。

津波予報の発表に責任を持つ気象庁は，全国を 6 地域に分割し，それぞれに津波予報中枢（管区気象台 なぞ）を置き，担当地域の地震津波の常時監視を行っている。遠地津波に関しては，津波予報全国中枢 （気象庁に置かれている）が担当している。

各中枢は，担当地域で，ある程度以上の地震を検知すると，その発生時刻，震源，マグニチュード，各 地の震度等をとりまとめ,「地震情報」としてマスコミなどを通じて速報する。海域の地震で，規模が大 きく, 津波の発生が㲘念される場合は，すべてに優先して津波予報作業にとりかかり，津波発生の有無， 予想される津波の程度，担当する沿岸への影響等を判断する。津波の危険が 予測される場合は，同時送 話（送画）装置，専用電話，テレタイプ等により，直ちに伝達機関に予報文を送付する。

（2）予報文を受け取った警察やNTT は，警察署や電話局を通じ，同時に各地の気象台から都道府県 の機関を通じ末端の市町村に, 海上保安庁は船舶に…… と予報は種々のルートを動員して伝達される。 市町村の防災機関は, 防災無線, 広報車, サイレン等で沿岸住民に知らせる。

* 2 段階の警報（大津波，津波）と4 種類の注意報（津波注意，その他）からなる。以下では複雑を さけるため，それらを厳密に区別せず，津波撆報と総称することもある。 
一方，NHK は津波予報を受けとると，たとえ深夜でも直ちに放送する体制を整えている。多くの民放 も津波予報の速報に協力する。放送は，警報などを広域の多数の人々に同時に伝達する手段として最も効 果的であり,これによる警報が 前記のルートによるものよりも先になることも多い。大きな摇れを感じた ら，先ずテレビやラジオのスイッチを入れることを襍めする。さらに，最近発足した緊急警報システム (EWS)* が普及すれば，放送の有効性は一段と高められることになろら。

津波警報は時間との戦である。津波監視の現場から直ちに沿岸へは無理としても，出来るだけ中継を排 し，より直接的な伝達により時間の短縮を計ることが必要である。

\section{V. 日本海中部地震と津波警報の限界}

（1）「日本海中部地震は津波警報がおくれ，多くの犠牲者を出した」と当時の新聞や雑誌に書かれてい る。事実, 儀牲者104人のうち, 100人は津波による死者である。なかでも, 遠足中の学童13人が津波にさ らわれたといら痛ましい事件を忘れることはできない。

津波警報が有効であるためには， $\mathrm{V}=\sqrt{\mathrm{gh}}(\mathrm{V}$ : 津波の速度, $\mathrm{g}$ ：重力加速度， $\mathrm{h}$ ：海の 深さ）** で 海岸に押し寄せる津波より早く，警報が沿岸の人々に屈けられねばならぬ。

日本海中部地震は正午に起こり, 担当津波予報中枢（仙台管区気象台）は14分後に「大津波」の警報を 伝達機関に送りこみ, NHK では12時19分に放送している。しかし，震源に近い海岸では地震後 7,8 分 で津波が（引き波で）始まり，12時15分ごろにはすでに第1波の山が押し寄せていた。

$「 1$ 分でも早く出して，1 人でも多くの命を救う」というのが津波警報の原則であるが，技術や体制の 限界を考慮して，規定では地震後20分以内に警報を出すよう定めている。14分で警報を出したのは，担当 者の極限的努力によるものと考光られる。また，警報は全く役に立たなかったわけでなく，ややはなれた 沿岸に対しては十分有効であったことが認められている。

規定上は合格であっても，な抢多くの犠牲者が出たという事実は深刻に受けとめられ，計算プログラム や作業手順の中から，秒を削る努力を積み重初，警報発表を数分早めることを可能とした。同時に，多く の作業に人手が介在する今のシステムでは，迅速化はすでに限界に近いことも明らかとなった。

（2）気象庁は津波警報の迅速化をめざし，大幅に自動処理機能をとりいれた「地震活動等綜合監視シス テム (EPOS)」の開発に取り組んだ。地震波形の自動読み取り, 震源のリアルタイム自動決定方式, 津 波判定作業の省力化, 発表文作製および伝達の機械化等により, かなりの時間短縮が可能となった。また, 津波到着予想時刻の計算, 津波の実況把握のための検潮データ解析等が容易となり, 情報サービスの充実 が計られるようになった。EPOS は，津波警報と同時に，東海地震の予知のための監視機能の強化 と いら任務を担っており，まず東京に 置かれることになった。このシステムの早期全国的な展開が望まれ る。

（3）津波を発生させるような大規模な地震の震源域は広く，震源（断層運動の始まった地点）が沿岸か らやや離れていても，津波の発生域（波源域）法沿岸にかなり近接していることが多い。日本海中部地震 の震源は沿岸から70 80km 沖に求められたが, 波源域は沿岸から $10 \mathrm{~km}$ 程度にまで及んでいたと推定さ れる。関東, 東南海, 南海道地震等の場合も同様で, 津波は地震後 5 分程度で始まっている。予想される 東海地震について同じことが考えられる。いかに自動化システムが進歩したとしても, 警報の迅速化に限 界のあることは明らかで，波源域に近い海岸に対して警報は無力である。海岸で強い地震を感じたら，そ れを警報と受けとり，直ちに自衛䘕動をとる以外には無い。

最近は，住居や産業施設などの海岸埋立地への進出が目立つ。また，夏季などに海浜レジャーに集う群

* 特別な装置（あるいは受信機）を用意すれば，受信機がオフ状態でも緊急警報放送の警報音（ある いは放送）が受信できる。

** 水深 $200 \mathrm{~m}$ で津波は時速 $160 \mathrm{~km}, 4000 \mathrm{~m}$ で $700 \mathrm{~km}$ 程度となる。 
衆は夥しい数にのぼる。このことは，日本海中部地震の教訓が示すように, 津波についての知識が, 最早 や海岸に居住する人々だけに必要なものではなくなっていることを意味する。「稲むらの火」のような教材 が教科書から消え去ったことは残念であるが, 啓蒙活動を強化し, 海岸で大地震にあった時の心得を広く 普及していく必要がある。

\section{VI. 津波の発生と地震}

（1）津波は，地震により生じた地形変動に伴う海水の擾乱現象で，海底の垂直変動が津波の発生を支配 することになる*。海底の垂直変動の量やその抎り，すなわち波源域の形状は，地震の規模だけでなく， 地震の発生メカニズムに左右される。我が国に津波をもたらす地震は，プレート境界の，いわゆる低角逆 断層型であることが多い。海面下にある津波の波源域の形状は，震源モデルや津波観測の結果からいろい ろと推定されているが，現在のところ，測地学的観測データーはほとんど無い。

沿岸に到達する津波の波形やそのエネルギーは, 津波の伝播距離だけでなく, 波源域の形状, 海底地形, 海岸線の形等により大きく変化する。しかし，それらの要素の影響は複雑で，量的関係を予測することは 困難である。また，波源域あるいはその近傍における（発生源での）津波に関する観測データも皆無に 近い。

このように，地震発生直後に，波源域の形状を推定し津波の発生やその程度を推定することは不可能に 近い。津波の伝播径路における複雑な条件をとりいれ，沿岸に到達する津波の大小を短時間で予測するこ ともむずかしい。このため, 功遅より拙速を尊ぶ津波予報においては, 多くの仮定にもとずく不安定な理 解計算よりも経験的法則に重点を置く。まず, 発生する津波の大小は, 単純に地震の規模（M）に比例す るとする。震源の深さの効果, 津波発生の地域性等を, 過去の事例に従い考慮にいれる。発生した津波は 伝播距離に従い減衰するとし，各地一の影響を予測する。この場合も，過去の事例が尊重される。

（2）最近100年間（1887 1986年）に，日本の沿岸で160回の地震による津波（近地津波，128回，遠地

第 1 表 階級別の津波回数 $(1887 \sim 1986$ 年)

\begin{tabular}{c|l|rl}
\hline \hline 階 級 & 津波の程度 & 回 & 数* \\
\hline $\mathrm{A}$ & 被害大 & 11 & $(1)$ \\
$\mathrm{B}$ & 被害あり & 16 & $(4)$ \\
$\mathrm{C}$ & 被害の可能性 & 19 & $(3)$ \\
$\mathrm{D}$ & 小 & 114 & $(24)$ \\
\hline \multicolumn{2}{|c|}{ 合 計 } & 160 & $(32)$
\end{tabular}

*（）遠地津波 $\mathrm{km}$ 以下の地震が152回（M7.5以上36回, M8以上7回）発生している。この約半数が津波を伴っている が，古い時代には小津波の観測もれもあるものと思われる。A，B，Cクラスの津波だけについてMと発生 率との関係を見ると，第1 図左のように，M7以上の $22 \%$ (34回)，M7.9以.上で100\%（11回）となる。

最近20年間（1967 1986年）に日本付近〔九州南方 (30N, 130E) から北海道東方沖 (46N, 148E) と する]の海域に, M6以上, 震源の深さ $100 \mathrm{~km}$ 以下の地震が128回（陸域には17回）発生している。 M 津波の発生率との関倸は，第 1 図右に示すように，M6以上の約 $1 / 4$ (29回)，M7以上は $100 \%$ (18回）津 波を伴っている。A，B，Cクラスの津波はM7以上の61\%（11回）となる。

（4）上記のことから，単純にMだけで津波の発生を予測した場合の適中率を調べてみる。Aクラスの津

*津波は海底火山の爆発，海底地过り，海岸の山崩れなどによって発生することがある。

** 津波の規模の数值的表現法については幾つかの提案があるが，ここで用いている階級は多分に便宜 的，且つやや主客的なものであることをお断わりしておく。

$$
-24-
$$


第 2 表 最近の主な津波災害

\begin{tabular}{|c|c|c|c|c|c|c|c|c|}
\hline 年 & 月 & 日 & & 地 震, & 津 & 皮 & $\begin{array}{l}\text { 津波による } \\
\text { 死 者 数** }\end{array}$ & $\begin{array}{l}\text { 津波の高 } \\
\text { さの最大 }\end{array}$ \\
\hline 1896 & 6 & 15 & 明 & 治 三 & 陸 & $\begin{array}{l}\mathrm{M}^{*} \\
8.5\end{array}$ & 約 22,000 人 & $24 \mathrm{~m}$ \\
\hline 1923 & 9 & 1 & 関 & & 東 & 7.9 & （約 140,000 人） & $12 \mathrm{~m}$ \\
\hline 1933 & 3 & 3 & 昭 & 和 & 陸 & $(8.5)$ & 約 3,000 人 & $23 \mathrm{~m}$ \\
\hline 1940 & 8 & 2 & 神 & 威 & 岬 & 7.5 & 10 人 & $3 \mathrm{~m}$ \\
\hline 1944 & 12 & 7 & 東 & 南 & 海 & 7.9 & (約 1,000 人) & $9 \mathrm{~m}$ \\
\hline 1946 & 12 & 21 & 南 & 海 & 道 & 8.0 & (約 1,400 人) & $6 \mathrm{~m}$ \\
\hline 1952 & 3 & 4 & + & 勝 & 沖 & 8.2 & (33人) & $7 \mathrm{~m}$ \\
\hline 1960 & 5 & 24 & チ & & リ & $(8.5)$ & 142 人 & $6 \mathrm{~m}$ \\
\hline 1964 & 6 & 16 & 新 & & 潟 & 7.5 & (26人) & $5 \mathrm{~m}$ \\
\hline 1968 & 5 & 16 & + & 勝 & 沖 & 7.9 & (52人) & $6 \mathrm{~m}$ \\
\hline 1983 & 5 & 26 & 日 & 本 海 中 & 部 & 7.7 & 100 人（104人） & $6 \mathrm{~m}$ \\
\hline
\end{tabular}

* MJ,（） は Ms

**（）は地震によるものとの合計

波は，第 2 表に示すように，いずれもM7.5以上 の地震で発生したものである。Aクラスの津波 に対するMの敷居值を 7.5 とすれば，過大評価 となることはあるが，見逃しは無くなる。B，C では, 敷居值 M7 で, 適中と過大との比率がほ じ等しい。また，小数の過小評価(最近100年間 に, M6.7でB, M6.9でCの 2 例)を生じる。津 波発生ということでは，敷居值 M7 で 100\%, から振り無し，M6.5に下げると, 適中 $3 / 4$, か ら振り $1 / 4$ 程度, M6.0では, 逆に, 適中 $1 / 4$,か らぶり $3 / 4$ 程度となる。なお, 最近 20 年間にM 6 以下で津波を伴った地震が 1 回（M5.9 でD） ある。
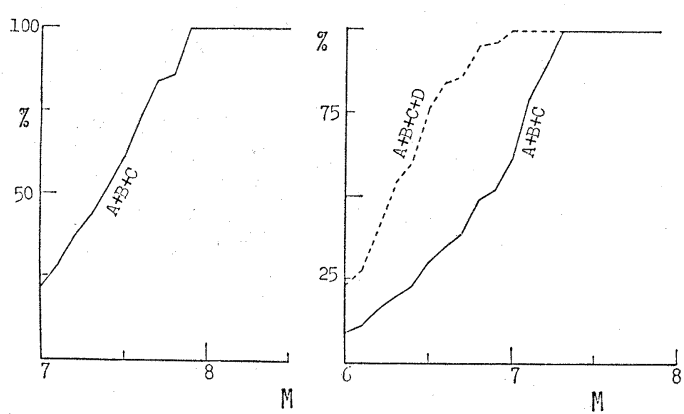

第 1 図 地震の $\mathrm{M}$ と津波の発生率 左；1887 1986年, 日本及び周辺 右；1967 1986年，日本近海

$\mathrm{A}, \mathrm{B}, \mathrm{C}, \mathrm{D}$; 第 1 表参照

現行の津波警報では, 予想される津波を 3 段階に分けている。その判定に当っては, 当然適中率を高め, 過大評值やから振りを避けることが望まれるが, 最も注意を払うのは, 過小評価や見逃しという危険を犯 さない事である。相容れない両者を調整して，予報の信頼性を高めていくのが今後の課題であるが，その ためには，M以外の要素を取り入れていか敢ばなるまい。

（5）津波の判定には，地震の規模を正当に評価することが決定的に重要である。地震の発生すなわち断 層の生成とみれば, 断層運動の大きさ（断層の面積 Sおよび変位量 D） から定義される地震モーメント （Mo）が地震の規模を表わすのに最もふさわしい, しかし, Mo $=\mu \mathrm{DS}$ ( $\mu$ : 剛性率) の計算は急場には間 に合わない。それに対して，Mは特定の周期の地震波の振幅で定義され，観測や算出がごく簡単で，実用 的である。ところが, 地震波は非常に広帯域の波から構成されており, そのスペクトルは地震の大小や起 こり方によって違っている。このため, ある周期の波だけに着目して地震の規模を評債すると不都合が生 ビることがある。

日本で広く用いられている気象庁マグニチュート $(\mathrm{MJ})$ は, 周期 5 秒程度の地震計に記録された地震 波の最大振幅を用いて算出される。このため, 数秒の波が卓越する MJ $5 \sim 6$ 前後の地震には好都合であ 
るが，ごく短周期の波から成る小さな地震や，長周期の波が優勢になる大きい地震の規模の評価には不都 合が生じる。また，かなり大きな地震でも，断層生成がゆっくり行なわれると，短周期の地震波は相対的 に微弱となり，震度も弱く感じられる。これに対して，大きなエネルギーを担う長周期の波は優勢となる が，地震計の周期が十分長くないと，このような長周期の波は記録されにくい。そのため，実際より小さ な地震に見えることになり，MJ は過小評価となる。海溝付近には，このような地震が発生し，津波を伴 うこともあるので注意を要する*。地震のMを過小評価することにより，津波を見逃したり過小評価したり するという危険をさけるためには，より長周期の地震計による観測が必要である。現在気象庁が開発して いる広帯域の電磁式強震計が全国に展開されれば，津波監視に威力を発揮することになろう。

（6）周期20秒前後の表面波の振幅から求められるマグニチュード（Ms）は，全世界で共通に用いられ ている。Ms は大規模な地震に対して MJ より有利なことが多い。しかし，Ms を直ちに（国内のデータ で）求めることは困難である。

断層のディメンジョンは，主として長周期の波に反映されるので，非常に大規模な地震となると，最早 や Ms でも手に負えなくなってしまう。たとえば，世界最大といわれる1960年チリ地震も，日本最大とい われる1933年三陸地震も，Ms で比べるとほぼ同等（Ms 8.5程度）と評価される。地震モーメントを用い て比較すると，チリ地震は三陸地震の40 50倍という巨大地震であったことがわかる。

巨大地震の実体を知るためには，非常に周期の長い波（100秒以上）に関する情報が必要となる。この意 味で, 現在進められているアジア・太平洋超高性能地震観測網計画（POSEIDON）が注目される。

\section{VII. 津波の観測}

（1）長波として海洋を伝わる津波の波面や波線は，HUGGENS の原理やレイ・トレーシング法を用いて 作図することができる。最近は, 細かいメッシュでの水剁のデイジタル・データが豊富になって来たので, 計算機を使い詳細で正確な津波伝播図（あるいは逆伝播図）が比較的容易に描かれるようになった。津波 伝播図は，津波の到達時刻の予測のほか，回折・反射等の解析，エネルギーの集中・発散の計算等に利用 される。

波源域の拡がりにかかわる問題を除けば，津波の第 1 波の到達時刻に関しては，実用上大きな問題はな い。しかし，後続波については未解決の問題が多く，波高の時間的推移（最大波出現時），津波の継続時間 等を予測することは困難である。また，発生源における津波の高さ，伝播径路での減衰，沿岸の海底地形 や海岸線の形と津波の増幅率との関係，その他津波の量的予報に必要な多くの要素が，未だ研究途上にあ る。

（2）津波の研究や対策を進める上で，まずその実体を正確に把握することが必要であることは言うまで もない。津波が海岸に近ずくと，セイシュを始め色々な影響が重なり，沖合にあったときとはかなり違っ た形となる。変調される以前の津波をとらえ記録することが重要である。そのための計器はごく少く, 観 測データもほとんどない。さらに，海岸に㧍いても，津波を目的として設置されている計器は少く, 潮汐 観測のために湾奥や港内に置かれている検潮儀を利用することが多い。検潮儀の周波数応答の特性は, 津 波の観測には不便なことが多く，短周期の津波の波高は実際よりかなり小さく記録される。また，大きな 津波の観測も困難なことが多い。

日本海中部地震では, 多くの人々が観察した津波の塑上高や浸水高（あるいはその痕跡）と, 情報等で 発表している津波の高さ（検潮儀による）とが，第 2 図に示すように，大きく相違することが問題となっ た。防災のための情報サービスにおいては, 両者の関係を明らかにしておく必要があろう。同時に, 津波 の高さや波高の定義に関する混乱をなくしていく努力も必要である。

（3）PTWC や ATWC (アラスカ) 等では, 検潮データにより津波の発生を確認した上で, 警報を出

* Slow Earthquake とか低周波地震, あるいは津波地震と呼ばれる。 
すが，我が国ではそのような時間的ゆとりはな い。しかし, 外洋において, いち早く津波現象を 捕えることが出来れば，警報の確認や実況の把握 に非常に有効である。気象庁は1978年 御 前崎 沖 に，1985年房総半島沖に海底地震常時観測システ ムを敷設したが，このシステムには津波計（水晶 式水圧計）が装備されている*。これによって外 洋の数 $\mathrm{mm}$ 以上の水位（あるいは海底）の変化 をキャッチできるので, 津波が外洋から伝播して 来た場合（まだ観測の機会は無い），沿岸より 20 分程度早く検知される可能性がある。また, 波源 域に関する情報（海底の変動も含め）や，外洋に おける津波波形が入手出来れば，津波の発生機構 の研究に大きく貢献することになろう。

\section{VIII. おわりに}

太平洋の北部は，日・米・ソ等の津波警報組織 により，ほぼ完全とカバーされている。しかし，

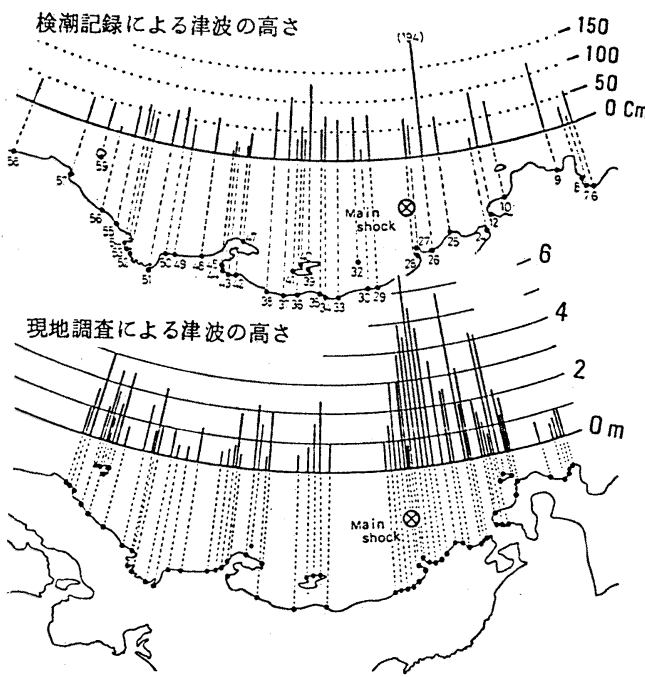

第 2 図 日本海中部地震の津波の高さ

上; 検潮儀による津波の高さの最大值 下; 証言や痕跡から求めた津波の高さ 中一南部では警報体制が不完全, あるいは全く無い地域も少なくない。

1976年ミンダナオ島沖の地震による津波は，モロ湾一帯を襲い，死者・行方不明者 8 千人以を出した と伝えられる。東南アジア地域は，一般に津波監視体制が不十分で，国際的にも，警報組織設立のための 援助の必要性が叫けばれている。Tsunami という世界共通の単語の発祥の地でもある津波先進国日本の, 西太平洋地域の津波警報に対する貢献を期待する声も高い。西太平洋地域における津波警報体制の確立 は，この地域の住民の防災に役立つだけでなく，我が国の遠地津波対策にも有益である。

現在，米国を中心に，人工衛星を利用し津波警報のための資料集収，警報の伝達手法（特に，発展途上 国を対象に）の開発が進められている。すでに，PTWC一チリ間では，衛星 GOESにより，実用化実験 が行なわれている。また, 衛星を介したリモート・センシングによる海面変化の検出の可能性も話題にの ぼっている。

通信衛星の利用は，津波監視の最前線である洋上の孤島や岬からの観測データ伝送，遠隔地への警報の 伝達に威力も発揮することになろう。津波警報体制をより発展強化するためには，この分野でも，国際協 力の下に研究開発を進めていく必要がある。

* 御前崎南南西約 $110 \mathrm{~km}$, 水深約 $2,200 \mathrm{~m}$ の地点。勝浦南東約約 $80 \mathrm{~km}$, 水深約 $4,000 \mathrm{~m}$ の地点, おょ び中間の 2 地点. 